\title{
Mantık ve Nahiv İlimlerinin Analojisini Kuran Filozof: Fârâbî
}

The Philosopher Who Found the Analogy of Logic And Nahiv Sciences: al-Fārābī

\author{
Ali SEVDİ \\ Dr. Öğr. Üyesi, Iğdır Üniversitesi, İlahivat Fakültesi, Temel İslam Bilimleri Bölümü, Arap \\ Dili ve Belagati Anabilim Dalı \\ Assist. Prof. Dr., Iğdır Universitv, Facultv of Theologv, Department of Basic Islamic Sciences, \\ Department of Arabic Literature \\ IĞDIR/TURKEY \\ alisevdi1984@hotmail.com \\ https://orcid.org/0000-0002-1951-7232 \\ Doi: 10.34085/buifd.988608
}

\section{Öz}

Antik Yunan dönemine ait eserlerin Arapçaya tercüme edilmesiyle birlikte ortak noktaları olmasının yanı sıra aslında iki farklı disiplin olan mantık ve nahiv ilimlerinden hangisinin daha üstün olduğu tartışmalarının baş gösterdiğine şahit olunmaktadır. Bu tartışmalar, mantık ile nahivin teorik yapısına ilişkin önemli görüşlerin doğmasına yol açmıştır. Fakat bu konuda uzlaştırıcı bir rol oynayan 10. yüzyıl İslam filozofu Ebû Nasr Fârâbî’ye göre ise mantık ilmi; toplumların lafızlarına yönelik ortak yasaları koyması bakımdan evrensel, nahiv ilmi ise sadece bir toplumun dilbilgisine ve lafızlarına yönelik yasaları belirlemesi yönüyle farklı iki disiplindir. Bununla beraber, nahiv biliminin lafızlar için belirlediği kuralların benzerlerini mantık biliminin de zihindeki akılsallar için belirlediğini söyleyen Fârâbî, bu ikisi arasında bir analojik bağ kurar. Hatta nahiv ilmi, özellikle başlangıçta mantık ilminin anlaşılması ve kolaylaştırılması bağlamında bir ön hazırlık olarak görülmüş ve ilimlerin sınıflandırılmasında nahiv ilmi en başta zikredilmiştir. Dolayısıyla gramer ilmiyle sözcükler arasındaki ilişkiyi, mantık ilmiyle akılsallar dediği anlamlar arasındaki ilişkiye benzeten Fârâbî göre bu iki ilim birbirine karşıt değil, birbirleriyle uyumlu iki disiplin olarak kabul edilmektedir. Bu sebeple ilgili kaynaklar taranarak Fârâbî'nin gramer ve mantık bilimi arasında kurduğu analoji, vuzuha kavuşturulmaya çalıșılmıştır. Bunun için çalışmada ilk önce kısaca Fârâbî'nin hayatına, mantık-nahiv kavramlarına, dil ve düşünce bağlamında mantık ile nahiv ilimlerinin etkileşimine değinildikten sonra, Fârâbî'nin öne sürdüğü mantık- nahiv analojisi incelenmiştir.

Anahtar Kelimeler: Fârâbî, Mantık, Nahiv, Arap Grameri, Dil.

\section{Abstract}

In addition to having common points with the translation of the works of the ancient Greek period into Arabic, it is witnessed that the debates on which of the two different disciplines, logic and syntax, are superior. These debates have led to the emergence of important views on logic and the theoretical structure of nahiv. However, according to the tenth century Islamic philosopher Abu Nasr al-Fārābī, who played a conciliatory role on this issue, the science of logic; It is universal in terms of establishing common laws for the words of societies, and syntax science is two different disciplines only in terms of determining the laws for the grammar and words of a society. In fact, the science of nahiv has been realized as a preliminary preparation in the context of understanding and facilitating the science of logic, especially in the beginning, and the science of nahiv has been mentioned first in the classification of sciences. Therefore, according to Fârâbî, who likens the relationship between grammar and words to the relationship between the science of logic and the meanings he calls rationals, these two sciences are not opposite to each other, but are accepted as two disciplines that are compatible with each other. For this reason, by scanning the relevant sources, the analogy that Fârâbî established between grammar and logic was tried to be clarified. For this reason, in the study, firstly, after briefly mentioning alFārābī's life, logic-nahiv concepts, the interaction of logic and syntax sciences in the context of language and thought, the logic-nahiv analogy proposed by al-Fārābī was examined.

Keywords: al-Fārābī, Logic, Nahv, Arabic Grammar, Language.

\section{GİRİŞ}

Düşünen ve düşüncelerini aktaran bir varlık olarak insan, duygu ve düşüncelerini lisân/dil vasıtasılyla aktarır. Düşüncesini aktarırken doğru ifade edilmesinde dilin kuralları kadar düşünmenin kuralları da önem arz eder. Bu anlamda deyim yerindeyse etle tırnak gibi nahiv denilen dil kuralları ile mantık ilmi, bilme ve anlama gibi özellikleriyle birbirinden ayrılmayan, bir birini kemale erdiren iki ilimdir. Ancak mantık ile nahiv arasındaki bu kopmaz bağa rağmen mantık, Arapça'ya girdiği ve İslâmî çalışmaların çeşitli dallarına nüfuz etmeye başladığı andan itibaren farklı İslâmî grupların 
güçlü bir direnișiyle karșı karşıya kalmıștır. Özellikle nispeten birbirleriyle ilișkili olan mantık ve nahiv ilimlerinden hangisinin üstün olduğu vb. hususlarda söz konusu ilimlerin temsilcileri arasında tartışmalar baş göstermiștir. Bunlardan "her ikisi"nin de gerekli olduğuna inanan Fârâbî, Kitâbü'lhurûf, İhṣấ 'ü'l- 'ulûm, el-Elfâzzü'l-müsta 'mele fi'l-manțk, et-Tenbîh 'alâ sebîli's-sa âde, el-Fusûulü'-hamse gibi mantık ve nahiv içerikli birçok eser yazmıștır. Bu gibi eserlerinde iki ilim arasındaki problemlere değindiği gibi mantıkla gramer arasında bir analoji kurarak bu konudaki tartıșmalara farklı bir boyut da kazandırmıstır. Makale, Fârâbî'nin ortaya koyduğu bu farklılıklara dikkat çekip mantık ve nahiv arasındaki analojinin tahlilini amaçlamaktadır. Diğer bir ifadeyle mantık ve nahiv arasındaki benzerliklerden veya ortak noktalardan hareketle biri için gerekli olanın diğeri için de geçerli olduğunu ortaya koymaktır. Bu anlamda makalede, ilkin gramer ve mantık kavramlarının analizine kısaca değinilecektir. Daha sonra dil ve düșünce bağlamında mantık ile nahiv ilimlerinin etkileșimi ve son olarak da filozofun, gramerle mantık bilimi arasında kurduğu ilișkiye ışık tutulacaktır. Ayrıca şunu belirtmeliyiz ki, her ne kadar Fârâbî her iki ilmin benzer yönlerini alıp aralarında bir analoji kuruyorsa da her ikisine de ayrı ayrı alanlar belirleme ve karșlaștırma gayretindedir de. Bu yüzden analoji her ne kadar var ise de bir karşılaștırma daha ön planda durmaktadır. Bu bağlamda Fârâbî'nin mantık-nahiv arasında kurduğu analoji ile birlikte çok detaya girmeden yer yer bu iki ilme yönelik karşılaştırmaya dair görüşlerine de değinilecektir.

\section{Ebû Nasr el-Fârâbî'nin Hayatına Kısa Bir Bakış}

Gerek klasik tabâkat kitaplarında gerek modern dönemde yapılan çalıșmalarda Fârâbî'nin özgeçmişi ve eserleri hakkında geniş malûmat ve yeterince çalışma yapılmış; onun yaşamı ve yaratıcılığı dikkatle incelenip çok değerli eserler ortaya konulmuștur. Fakat araştırdığımız kadarıyla Farabi'nin mantık ve nahiv ilimleri arasında kurduğu analoji konusunda istenilen anlamda detaylı bir araștırma yapılmamıștır. Dolayısıyla bu konudaki eksiklik makaleyi yazmamızın da etkin faktörü olmuş; sözünü ettiğimiz boşluğu doldurmak amacıyla az da olsa katkı sağlamaya gayret gösterilmiștir. Bu bağlamda asıl konuya odaklamak bağlamında Fârâbî'nin hayatı teferruatlı bir șekilde ele alınmayacaktır. Ancak Fârâbî'nin hayatı ve yetiștiği kültürel ortam hakkında kısaca bilgi vermenin konumuzun anlaşılması ve toparlayıcı olması bakımından faydalı olacağı kanaatindeyiz.

Batı âleminde "Alfarabius" ya da "Avennasar" diye bilinen Fârâbî'nin tam adı Ebû Nasr Muhammed b. Muhammed b. Tarhan b. Uzluğ el-Fârâbî'dir. Kesin olmamakla birlikte kendisi Maveraünnehir bölgesinde Fârâb ilinin Vesic köyünde yaklaşık olarak 257/870 yılında dünyaya geldiği rivayet edilmektedir. ${ }^{1}$

Fârâbî ilköğrenimine doğduğu yer olan Vesic'te bașlamıștır. Entelektüel yașamının çoğu ise belirli bir felsefe ekolüne bağlı olarak yetiștiği Bağdat'ta geçmiștir. ${ }^{2}$ Fârâbî, daha çok felsefe alanında meșhur bir filozof olarak tanınmıs olmasına rağmen, felsefenin doğrudan ya da dolaylı olarak ilgili bulunduğu diğer ilmî alanlarda da bir aktör olarak karşımıza çıkmaktadır. ${ }^{3} \mathrm{O}$, İslâm felsefesini; metot,

\footnotetext{
1 İbnü'l-Kıftî, Ebü'l-Hasen Cemâlüddîn Alî b. Yûsuf b. İbrâhîm b. Abdilvâhid eş-Şeybânî, İhbârü'l- 'ulemâ' bi-ahbâri'l-ḥükemâ', thk. İbrâhîm Şemsuddîn (Beyrut: Dâru Kütübi'l-'İlmiyye, 2005), 210; İbnü'n-Nedîm, Ebü’l-Ferec Muhammed b. Ebî Ya'kūb İshâk b. Muhammed b. İshâk, el-Fihrist, thk. İbrahim Ramadân (Beyrut: Dâru'l-Ma'rife, 1997), 321-322; İbn Hallikân, Ebü'l-Abbâs Şemsüddîn Ahmed b. Muhammed b. İbrâhîm b. Ebî Bekr el-Bermekî el-İrbilî, Vefeyâtü'l-a 'yân ve enbâ 'ü ebnâ 'i'z-zamân, thk. İhsân Abbâs (Beyrut: Dâru Șadr, 1977), 5/103; Safedî, Ebü's-Safâ (Ebû Saîd) Salâhuddîn Halîl b. İzziddîn Aybeg b. Abdillâh, el-Vâfi bi'lvefeyât, thk. Ahmed Arnâut- Türkî Mustafâ (Beyrut: Dâru Ihyyâi't-Türâs, 2000), 1/153; Beyhakī Zahîrüddîn, Ebü'l-Hasen Alî b. Zeyd b. Muhammed, Târîhu hü̈kemâ'i'l-İslâm, thk. Muhammed Kürd Ali (Dımaşk: y.y., 1946), 30-35; Şemsüddîn, Ahmed, el-'Alâm mine'l-felâsife (Beyrut: Dâru Kütübi'l-'Illmiyye, 1990), 11-15; Sâid el-Endelüsî, Ebü'l-Kāsım Sâid b. Ahmed b. Abdirrahmân elEndelüsî el-Kurtubî et-Tuleytılî, Tabakātü'l-ümem, çev. Ramazan Şeşen (İstanbul: Türkiye Yazma Eserler Kurumu Başkanlığı, Yayınları, 2014), 148-150; Ebû Nasr Muhammed b. Muhammed b. Tarhan b. Uzluğ el-Fârâbî, Kitâbu'l-Hurûf, çev. Ömer Türker (İstanbul: Litera Yayıncllık, 2008), 1-2; Feriedrich Dieterici, Alf Arabis Philosophische Abhandlungen, (Leiden: E.J. Brill, 1890), 115118; İbrahim Emiroğlu, "Mantık", Türkiye Diyanet Vakfi İslam Ansiklopedisi (Ankara: TDV Yayınlar1, 2003), 28/18-28.

2 İbnü'l-Kıftî, İhbârüll- 'ulemâ' bi-ahbâri'l-hükemâ', 210-212; İbn Hallikân, Vefeyâtü'l-a yân, 5/153-157; Safedî, el-Vâfî bi'l-vefeyât, 1/102-105vd.; Şemsüddîn, Ahmed, el-'Alâm mine'l-felâsife, 10; İbrahim Hakkı Aydın, Farabi'de Metafizik Düşünce (İstanbul: Bil Yayınları, 2000), 14-15.

3 İbnü'l-Kıftî, İhbârü'l- 'ulemâ' bi-ahbâri'l-hükemâ', 210-212; İbnü'n-Nedîm, el-Fihrist, 321-322; İbn Hallikân, Vefeyâtü'l-a 'yân, 1/153157; Şahin Filiz, Farabi (İstanbul: İnsan Yayınları, 2005), 14.
} 
terminoloji ve problemler açısından temellendirmiş, Fârâbîcilik doktrini ile düşünce dünyasında yeni bir çı̆̆ır (İslâm Rönesans'1 Çağı) açmıştır. ${ }^{4}$

İslâm felsefesinin en güçlü filozoflarından biri sayılan Fârâbî, İslâm âleminde ilk olarak felsefeyi en iyi șekilde anlayan ve temellendiren, Aristoteles'in (m.ö. 384-322) eserlerini șerh ve izah eden, mükemmel bir șekilde yorumlayan kiși olarak kabul edilmektedir. Bu özelliklerinden dolayı kendisi, "ilk öğretmen" olarak anılan Aristo'dan sonra ikinci öğretmen (el- Muallimü's-Sânî) unvanıyla tanınmış; felsefe ve düșünce tarihinde de bu sekilde nitelendirilmiștir. ${ }^{5}$ Fârâbî, felsefenin İslâm dünyasına geçiși sırasında Grekçe ve Arapça kelimeler arasında anlamsal bir münasebet kurup, karşılıklarının bulunmasında önemli rol oynamıștır. Bilindiği gibi bugün kullandığımız felsefî terimlerin birçoğunun kaynağı Grekçe-Latince'dir. Felsefenin İslâm dünyasına girmesiyle bu kavramların Arapça karşılıkları bulunmaya çalışılmıștır. Bu konuda derin ilmî birikime sahip olan Fârâbî, Grekçe ve Arapça kelime kalıplarının ötesine geçip lafızların ruhu mesabesindeki manaların derinliklerine inerek onlara, bilimsel zeminde İslâm düșünce havzasına katmıștır. Böylece Fârâbî Gerek anlam dünyasından aldığı felsefî değerleri isimlendirme problematiğini çözümleyerek kendi orijinalitesiyle Arap anlam dünyasına kazandırmıştır. ${ }^{6}$

Fârâbî'nin Arapça'ya ve aynı zamanda Grekçeye olan hâkimiyetinin göstergesi olarak nitelendirebileceğimiz bu durum aynı zamanda bilimin evrensel vasfının bir tezahürü olarak da kendini göstermektedir. ${ }^{7}$

Hâsılı, bütün hayatını ilme adayan ve bıraktığı eserlerle çağları aydınlatan Fârâbî, mütevazı bir hayattan sonra 950 yılında 80 yaşındayken bugünkü Şam topraklarında hayata veda etmiştir. ${ }^{8}$

\section{Mantık ve Nahiv Kavramları}

\subsection{Mantık}

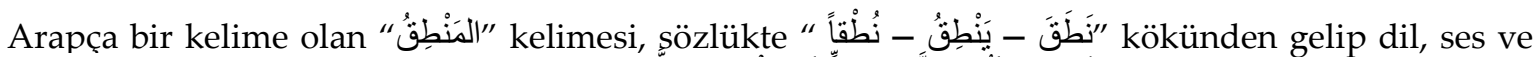

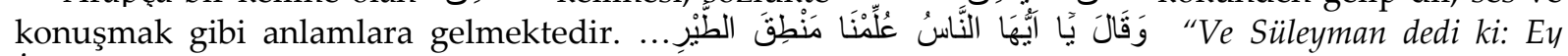
İnsanlar! Bize kuş dili öğretildi" âyetinde "mantık" kelimesi bu anlamda kullanılmıştır.9 Sarf ilmi

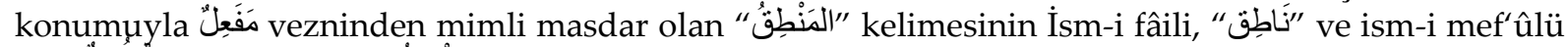

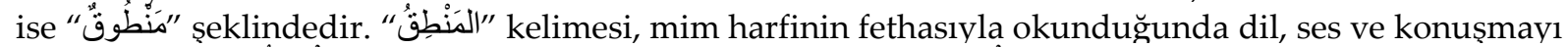
ifade ederken, "الِِنِطِيقُ vezninde mübâlağa ism-i fâil olup beliğ ve çok güzel konuşan kişiyi ifade etmektedir. ${ }^{10}$

Arap dili terminolojisinde ise mantık ilmi için gerek klasik gerek modern mantıkçılar tarafından farklı tanımlar yapılmıştır. Ancak genel anlamda mantık ilmi terim olarak “düşünme ve konuşma

\footnotetext{
${ }^{4}$ Mahmut Kaya, “Fârâbî”, Türkiye Diyanet Vakfı İslam Ansiklopedisi (İstanbul: TDV Yayınları, 1995), 12/162-163.

5 İbnü'l-Kıftî, İhbârü'l- 'ulemâ' bi-ahbâri'l-hükemâ', 210-212; İbnü'n-Nedîm, el-Fihrist, 321-322; İbn Hallikân, Vefeyâtü'l-a 'yân, 5/153157; İbn Hallikân, Vefeyâtü'l-a yân, 1/153-157; Encyclopedia of Islam, Leiden: E.J. Brill, 1980, Farabi Md.

${ }^{6}$ Ayrıntılı bilgi için bk. Soheil M. Afnan; İbnü'l-Kıftî, İhbârü'l- 'ulemâ' bi-ahbâri'l-hükemâ', 210-212; İbn Hallikân, Vefeyâtü'l-a yân, 5/153-157; İbn Hallikân, Vefeyâtü'l-a 'yân, 1/153-157; Philosophical Terminology in Arabic and Persian (Leiden: E. J. Brill, 1964); İsmail Erdoğan, “ Bazı Felsefi Kavramlara Divan-ı Lügati't-Türk'ten Karşılık Olabilecek Terim Örnekleri”, Firat Üniversitesi Illahiyat Fakültesi Dergisi 17/1 ( 2012), 18; Hasan Ayık, "Felsefi Kavramların Oluşmasında Farabî'nin Rolü", Gazi Üniversitesi Çorum Ilahiyat Fakültesi Dergisi 4/7(2005), 85-87.

${ }^{7}$ Mirpenç Akşit, "Fârâbî Düşüncesinde Mantığın Dili ve Anlamı", Uluslararası Sosyal Araştırmalar Dergisi 11/56 (2018), 247.

8 İbnü'l-Kıftî, İhbârü̈l-'ulemâ' bi-abbâri'l-hükemầ', 210-212; İbn Hallikân, Vefeyâtü'l-a 'yân, 5/153-157; İbn Hallikân, Vefeyâtü'l-a yân, 1/153-157; Sâid el-Endelüsî, Tabakātü'l-ümem, 150; Anthony Robert Booth, Analitik İslam Felsefesi, çev. Emel Sünter- Mirpenç Akşit (Konya: Eğitim Yayınları, 2020), 82-87.

${ }_{9}$ En-Neml 27/16.

${ }^{10}$ Ebü'l-Fazl Cemâlüddîn Muhammed b. Mükerrem b. Alî b. Ahmed el-Ensârî er-Rüveyfiî İbn Manzûr, Lisânu'l-'Arab (Beyrut: Dâru Ṣadr, 1414), 10/ 354-355; Ebü't-Tâhir Mecdüddîn Muhammed b. Ya'kūb b. Muhammed el-Fîrûzâbâdî, el-Kāmûsü'l-muhît (Beyrut: Mektebetu't-Tahkîk ve't-Turâs fî̀ Müessesetü'r-Risâle, 2005), 1/926; Ebû Nasr İsmâîl b. Hammâd el-Cevherî, Tâcü'l-lugga, thk. Ahmed Abdulğafûr Attâr (Beyrut: Dâru'l-'İlmi lil-Melâyîn, 1987), 26/219; Ebû Abdillâh Zeynüddîn Muhammed b. Ebî Bekr b. Abdilkādir er-Râzî, Muhtârü'ṣ-șihâh, thk. Yusuf Şeyh Muhammed (Beyrut: Dâru Numuziciyye, 1999), 1/313; Ahmed Muhtar Abdulhamid Ömer, Mu'cemu'l-Luğati'l-Arabiyyeti'l-Muâstra (Beyrut: Âlemü'l-Kütüb, 2008), 2229-2230.
} 
faaliyetinde zihni hatalardan koruyan, doğru düşünmenin yasallarını, ölçülerini ve yöntemlerini gösteren bir sanat veya ilim dalı" şeklinde tanımlanır. ${ }^{11}$

İslâm bilginleri, genellikle mantığ "bilinenden bilinmeyenin elde edilmesine vasıta olan ilim" 12; "kurallarına uyulduğunda zihni hataya düşmekten koruyan bir fen"13; "insanı, fikrin sahihini fâsidinden ayırmaya muktedir kılacak kuralları veren alet ilmi"14 şeklinde tanımlamışlardır.

Fârâbî ise İhṣâ 'ü'l- 'ulûm (Bilimlerin sınıflandırılması) adlı eserinde المَنْطِقُ "mantık" kelimesinin tahlilini yaparken ayn şekilde bu kelimenin النُّنُ "nutk" masdarından türediğini belirtir. Fârâbî bu

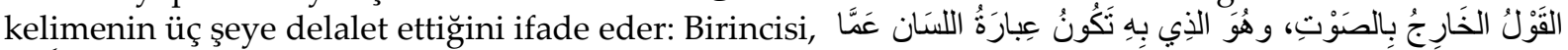
"Insanın zihinde bulunan düşüncelerin dile getirilmesidir ki, bu dış konuşma (en-nutku’l-

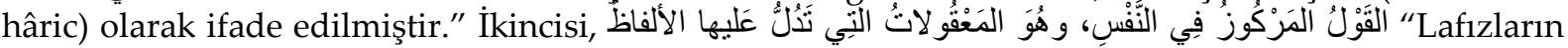
delalet ettiği zihindeki düşüncelerdir/anlamlardır ki, bu da iç konuşma (en-nutku'd-dâhil/ iç nutuk)

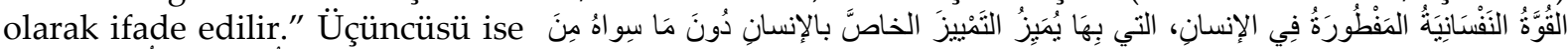
أinsanın yaratıllısı itibariyle sahip olduğu ruh kuvvetidir. Tüm canlılar arasında sadece insana has olan ayırt etme yetisi bu kuvvet sayesinde olur. Aynı şekilde insanın; akılsalları, ilimleri ve sanatları elde etmesi de bu yeti sayesindedir." Bu yeti ile insan eşyanın hakikatini idrak ettiği gibi eylemlerinde güzel ve çirkin olanı da birbirinden ayırt eder.

Fârâbî mantık ilminin tanım ve gayesini ise şu şekilde dile getirmektedir:

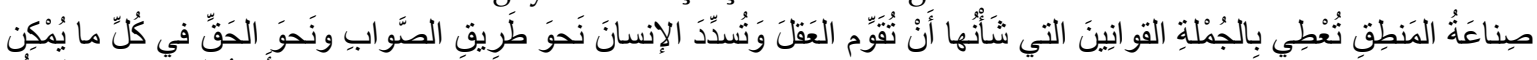

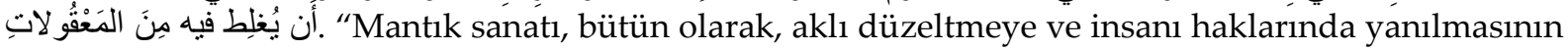
mümkün olduğu bütün akılsallarda (ma'kûlât) doğru yola, hakikate götürmeye yarayan kanunları koyan bir ilimdir."15 Tanımdan da anlaşıldığı üzere Fârâbî, mantık ilmi için ayırt etme/temyiz gücü kavramını kullanır. Ona göre mantık sanatı, insan için bilme konusu olan her nesne ile ilgili bilgilerin kazanılmasını sağlayan, zihni düzeltmeye, insanı doğru yola ve gerçek tarafa yöneltmeye yarayan yasaları veren bir güçtür. ${ }^{16}$ Böylelikle Fârâbî İslam düșüncesinin zihin yapısı içinde mantığa yeni anlamlar kazandırmıș, bu iki bilim arasında kurduğu analoji ise aslında gelecek satırlarda görüleceği gibi الرَنْطُقُ "mantık" kelimesinin bu tahlil ve analizi, dolayısıyla "nutk" teorisinin içinde bulunmaktadır. ${ }^{17}$

Mantık, doğruyu yanlıştan ayırt etmenin ölçüsü; zihni, yanlıştan korumanın tekniği; doğru, sağlam ve kesin (burhânî) delilleri göstermenin kıstası; ilimlerin yol ve metot gösteren rehberi gibi özelliklerinden dolayı önemli bir alet ilmi olarak görülmüştür. Bu önemine inandıklarından dolayıdır ki atalarımız, mantık eserlerini asırlarca medreselerde okumuş, şerh etmiş ve okutmuşlardır.18 Mantık dersleri, kadim medrese geleneğinde genellikle öğrenci sarf-nahiv gibi ilimlerde meleke kazandıktan sonra okutulurdu. Günümüzde, İlahiyat fakültelerinin ilk açılıșından itibaren ders programlarına dâhil edilen bu bilim, yeteri miktarda olmasa da önemli bir alan olarak okutulmaktadır.

\subsection{Nahiv}

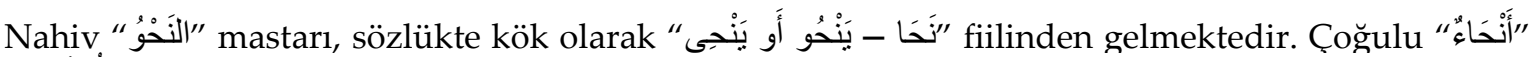

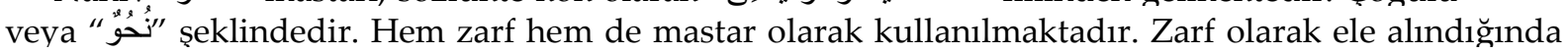
sözlükte "yön, taraf, cihet ve yol" gibi anlamlara; mastar olarak kullanıldığında ise "kastetmek, yönelmek, meyletmek ve tahrif etmek" gibi anlamlara gelmektedir. Nitekim nahiv kelimesinin bu son

\footnotetext{
${ }^{11}$ Kutbüddin er-Râzî, Ebû Abdillâh Muhammed b. Muhammed et-Tahtânî, Tahrîrü'l-kavâ 'idi'l-manțkıyye fî şerhii'r-Risâleti'şşemsiyye (İstanbul: y.y., 1288), 10-13; Kazvinî, Ebü'l-Hasen Necmüddîn Debîrân Alî b. Ömer b. Alî el-Kâtibî, er-Risâletü'ş-şemsiyye fi'l-kavâ 'idi'l-manțkıyye, thk. Mehdî Fazlüllâh (Beyrut: Merkezü's-Sekafi'l-Arabî, 1998), 44-45; Ali Sedâd, Mîzânü'l-'ukûl fi'l-mantık ve'l-usûl (İstanbul: Y.y. 1303), 6; Emiroğlu, “Mantık”, 28/18.

${ }^{12}$ Kutbüddin er-Râzî, Şerḥu'ş-Şemsiyye, 10.

${ }^{13}$ Ebü'l-Hasen Alî b. Muhammed b. Alî es-Seyyid eş-Şerîf el-Cürcânî el-Hanefî, Mu'cemu't-ta 'rîfât, thk. Muhammed Sıddık Minşâvî (Kahire: Dâru'l-Fâḍila, ts.), 196; Ali b. Ömer el-Kazvînî, eş-Şemsiyye fi'l-kavâ 'idi'l-manțkıyye (İstanbul: y.y., 1290), 3, 10, 16,31 .

${ }^{14}$ Sedâd, Mîzânü'l-ukūl fi'l-mantık ve'l-usûl, 6-7; Emiroğlu, "Mantık", 28/19-20.

${ }^{15}$ Fârâbî, İhṣâ' 'ü'l- 'ulûm, 21-22.

16 Fârâbî, Kitabü't-Tenbîh ala Sebîli's-Saâde, 253.

${ }^{17}$ Fatma Dore, "Fârâbî'nin Gramer-Mantık Analojisinde Nutk", ETHOS: Felsefe ve Toplumsal Bilimlerde Diyaloglar 12/1,(2019), 5455.

18 İbrahim Emiroğlu, Klasik Mantığa Giriş (Ankara: Elis Yayınları, 2010), 1-3.
} 
manasına dayanılarak, bu ilme önem veren ve bu ilimle uğraşanlar hakkında, cümleye/kelama i'raba göre şekil verip değiştirdikleri için “النَخْوِيُون" ismi kullanılır.19

Arap dili terminolojisinde nahiv ilminin tanımı noktasında Arap dilbilimcileri arasında ihtilaflar ortaya çıkmış ve çeşitli tanımlar ileri sürülmüştür. Ancak hepsinin birleştikleri ortak payda ise nahiv ilminin, -mantık sanatını çağrıştırır şekilde- konuşma esnasında dili hatalardan koruyan, doğru konuşmanın kurallarını, ölçülerini, yöntemlerini gösteren ve belirleyen bir ilim dalı olmasıdır.

Nahiv ilminin ortaya çıkışı konusunda gerek klasik gerekse modern kaynaklarda hem dinî hem de siyasî etkenlerin olduğu ifade edilmektedir. Çalışmanın hacmini aşacağı için bu detaylara girilmeyecektir. ${ }^{20}$ Fârâbî ise nahiv ilminin, diğer bütün ilimler gibi Arap kültürü ve buna bağlı olarak bazı zaruri ihtiyaçlar neticesinde ortaya çıktığına vurgu yapmaktadır.

Nahiv ilminin gelişimini tamamlayıp bağımsız bir ilim haline gelmesi Hicri ikinci asrın ortalarına denk gelmektedir. Bu da Antik döneme ait mantık eserlerinin Arapçaya tercüme edilmeye başlandığı bir zaman dilimine denk gelmektedir. Bu tarihi vakıadan hareketle nahiv ilmi olarak bilinen Arap gramerinin Yunan grameri, felsefe ve mantığından etkilendiğini savunanlar olduğu gibi nahiv ilminin tüm yasa ve kurallarını Arap kültürünün temelinden aldığını savunanlar da olmuştur. Dolayısıyla mantık ile nahiv arasında bir bağlantının olup olmadığı veya hangisinin daha üstün olduğu hususunda tartışmalar baş göstermiştir. Nitekim tercüme faaliyetleriyle birlikte mantık ilmine gösterilen ehemmiyetten dolayı bu zümrenin mensuplarıyla İslâm vahyinin etkisiyle ortaya çıkmış olan ilimlerle uğraşan kesimler arasında gerilimler yaşanmış -özellikle gramerciler (nahviyyûn)tarafından güçlü bir tepkiyle karşılanmıştır. ${ }^{21}$

Gramerciler, mantığa kendi dil ve dinlerine meydan okuyan gayri İslâmî bir medeniyetin unsuru olarak bakmış, ondan uzak kalınması gerektiğini savunmuşlardır. ${ }^{22}$ Ancak bu şekildeki karşı çıkışlarının yanında iyimser bir yaklaşım sergileyerek arabulucu rolünü üstlenenler de olmuştur. Bunların başında ileriki sayfalarda da ifade edileceği gibi şüphesiz Fârâbî gelmektedir.

\section{Dil ve Düşünce Bağlamında Mantık İle Nahiv İlimlerinin Etkileşimi}

Fârâbî, hem lugavî hem de șer'î ilimlerin zirveye ulaștığı; Müslümanların Antik Yunan mantığı, felsefesi ve ilmiyle, dolayısıyla Yunan kültürüyle tanıștı̆̆ı bir ortamda yașamıștır. $O$, önde gelen diğer İslâm filozoflarından farklı olarak daha çok mantık ilminde uzmanlaşmıș, engin ilmî birikimiyle özellikle de Ya'kūb b. İshâk el-Kindî (öl. 252/866) ve diğer mantıkçıların çözümsüz bıraktıkları Helen felsefesinin anlaşılmayan muğlak meselelerini çözüme kavuşturmuştur. Arap ve İslâm kültürünün

\footnotetext{
19 İbn Manzûr, Lisânu'l-'Arab, 15/310; Fîrûzâbâdî, el-Kāmûusü'l-muhịt, 1/1337; Cevherî, Tâcü'l-lugga, 11/2503; Ebü'1-Feyz Muhammed el-Murtazâ b. Muhammed b. Muhammed b. Abdirrezzâk el-Bilgrâmî el-Hüseynî ez-Zebîdî, Tâcü'l- 'arûs min cevâhiri'l-Kāmûs (Beyrut, y.y., 1994), 20/26; Ebü'l-Hüseyn Ahmed b. Fâris b. Zekeriyyâ b. Muhammed er-Râzî el-Kazvînî el-Hemedânî, Mu 'cemü mekāyîsi'l-lugia (Beyrut, y.y., ts.), 5/403; Muhammed Ali et-Tehânevî, Mevsû'atu keşşâfi ıstılâhâti'l-funûn ve'l-'ulûm (Beyrut, y.y., 1996), 2/684.

${ }^{20}$ Zira bu iki ilmin teşekkülünün ilk safhasından son safhasına kadar ciddi ve bilimsel birçok çalışma yapılmıştır. Detaylı ve geniş bir şekilde bkz. Ebû Saîd es-Sîrâfî, Ahbârü'n-nahviyyîne'l-Basriyyîn, nşr. Muhammed İbrâhîm el-Bennâ (Kahire: Dârü'lİtisâm, 1985), 10-20; İbnü'n-Nedîm, el-Fihrist, 45-50; Ebü'l-Berekât İbnü'l-Enbârî, Nüzhetü'l-elibbâ fî tabakati'l-üdebâ, nsr. İbrâhim es-Sâmerrâî (Ürdün: Mektebetü'l-Menâr, 1985), 18-23; İbnü'l-Kıftî, Ebü'l-Hasan Cemâleddin b. Yûsuf b. İbrâhîm eş-Şeybânî, İnbâhü'r-ruvât alâ enbâi'n-nuhât, nşr. M. Ebü'l-Fazl İbrâhim (Kahire: Dârü'l-Kütübi'l-Misriyye, 1995), 39-56; Muhammed etTantâvî, Nes'etü'n-nahv ve târîhu eşheri'n-nuhât ( Kahire: Dârü'l-Menâr, 1991), 16-49; Saîd el-Efgânî, Min Târîhi'n-nahv (Beyrut: Dârü'l-Fikr, 1978), 7-45; Abdülâl Sâlim Mekrem, el-Halkatü'l-mefkude fî târîhi'n-nahvi'l-Arabî (Beyrut: Müessesetü'r-Risâle, 1993); Mâzin el- Mübârek, en-Nahvü'l-Arabî el-'illetü'n-nahviyye: Nes'etühâ ve tetavvürühâ (Beyrut: Dârü'l-Fikr, 1981); Şevki Dayf, elMedârisü'n-nahviyye (Kahire: Dârü'l-Ma'ârif, 1968), 9-22; Mâzin el- Mübârek, en-Nahvü'l-Arabî el-'illetü'n-nahviyye: Neş'etühâ ve tetavvürühâ (Beyrut: Dârü'l-Fikr, 1981); Gerhard Endress, “el-Münâzaratü beyne'l-mantıkı'l-felsefî ve'n-nahvi'l-Arabî fi usûri'lhulefâ", Mecelletü târîhi'l-ulûmi'l-Arabiyye, 1/2, Halep 1997; Veledu Ebbâh, Muhammed Muhtâr, Tarihu'n-Nahvi'l-Arabiyyi fi'lMeşrik ve'l-Meğrib (Beyrut: Dâru Kütübi'l-İlmiyye, 1971): Muhammed Ahmed Muhammed eş- Şâtır, el-Mûciz fî Neş'eti'n-Nahv (Kahire: Mektebetü'l-Külliyati'l-Ezheriyye, 1983); Fuat Sezgin, Târîhu't-Turâsi'l-Arabî, çev. Mahmûd Fehmî Hicâzî (Riyad: İdâretu's-Sekâfe ve'n-Naşr Câmiatu İmâm Muhammed b. Suûd el-İslâmiyye, 1991).

${ }^{21}$ İbnü'1-Kıftî, İnbâhü'r-ruvât alâ enbâi'n-nuhât, 3/149; T.J. De Boer, İslam'da Felsefe Tarihi, çev. Yaşar Kutluay (İstanbul: Anka Yayınları, 2004); Ahmed Emîn b. İbrâhîm et-Tabbâh, Duha'l-ìslâm (Kahire, y.y., 1933), 1/298; Mirpenç Akşit, Fârâbî'de Mantığın Dili ve Dilin Mantığı Üzerine Bir Anlam Arayışı (Erzurum: Atatürk Üniversitesi, Sosyal Bilimler Enstitüsü, Doktora Tezi, 2017), 8587.

${ }^{22}$ Emiroğlu, “Mantık”, 28/18-28.
} 
mantıkla ilișkisini kurarak yeni bir çığır açmıștır. Ayrıca onun yaşadığı dönem merkezî devletlerin emirlik ve devletçiklere bölündüğü dönem olarak nitelendirilmektedir. Bunun bir neticesi olarak sosyal, siyasal ve fikirsel anlamda tartışmaların yoğun olduğu; kaçınılmaz bir şekilde dönemin önde gelen filozoflarının bu gibi sorunlara çözüm üretmek çabasıyla analist ve tartıșmacı olarak münazaralara dâhil oldukları görülmektedir. Bu meseleler, dönemin ünlü dilcilerinden Ebû Saîd esSîrâfî (öl. 368/979) ile mantıkçı Mettâ b. Yûnus (öl. 328/940) arasında dil, felsefe ve mantık konularında yapılan münazaraların bir yansıması olarak çağın ünlü müfekkirelerin ilgilerini ciddi bir şekilde çektiği gibi Fârâbî'nin de zihnini kurcalayan ve meşgul eden sorunlardan biri olmuştur. ${ }^{23}$

İslâm literatüründe "mantık-nahiv tartıșmaları" olarak geçen bir dizi münazaranın en ünlüsü olan bu olay, Arap dilbilimcisi, kelâm, fıkıh bilgini Sîrâfî ile Süryani mütercim ve mantık hocası Mettâ b. Yûnus arasında 326/932 yılında gerçekleșen nahiv-mantık tartışması, gerek nahiv gerekse mantık alanında Fârâbî gibi önemli şahsiyetlerin yaşadığı önemli bir dönemde gerçekleşmiștir. Münazarada Yunan mantığı ile Arap nahvinin birbirine nispetle üstünlüklerine dair yapılan tartışma metni Ebû Hayyân et-Tevhîdî (öl. 414/1023) tarafından el-İmtấ ve'l-Muânese eserinde aktarılmıștır. Bu "tartışmadan sonra artık sadece nahvin ya da sadece mantığın bilinmesiyle her seyin bilinebileceği iddiaların öne sürüldüğü dönem bitmiş, her ilim, durması gereken yeri bilir hale gelmiștir. Mantık ve nahiv ilimlerinin konu ve amaçları ayrı ayrı belirlenmiştir." ${ }^{24}$ Tartışmada dile getirilen çeşitli argümanlar, daha sonra özellikle mantık konusunda uzmanlığıyla bilinen bașta Fârâbî olmak üzere mantıkçılar tarafından geliştirilirken buna karşılık nahivciler de kendi argümanlarını güçlendirme yollarını aramışlardır. ${ }^{25}$

Bu iki bilgin arasında gerçekleșen münazaranın Fârâbî’yi açıcça etkilediği görülmektedir. Hatta onun Kitâbu'l- Hurûf ve el-Elfâzü'l-müsta'mele fi'l-mantık adlı eserlerindeki görüşleri ile bu mecliste cereyân eden ve Sîrâfî́nin Mettâ $b$. Yûnus'a yönelttiği ve kendisinin birçoğunu cevaplamakta aciz kaldığı veya ikna edici cevaplar veremediği sorulara verilen cevapları içerir niteliktedirler. Fakat gerek mantık gerek nahiv ilmini çok iyi bilen; tartışmanın meydana geldiği dönemde mantık ilminin önde gelen önemli temsilcilerinden sayıldığı ve dönemin devlet ricâli yanında önemli bir yeri olduğu halde Fârâbî'nin, o mecliste olmayıșı yadırganmıștır. ${ }^{26}$ Çünkü Arap grameri ve fıkhını bilmediği -ki bundan dolayı muhatabını mantık ile nahiv ilişkisi konusunda ikna etmekte zorlanan mantıkçı Mettâ b. Yûnus - Sîrâfî tarafından eleştirilmiştir.

İki bilgin arasında gerçekleșen tartıșmada Mettâ b. Yûnus'un yenik düșmesinin en büyük nedenlerinden biri de onun, nahiv ile mantığ karşılaștıırıken nahiv ilminden haberdar olmamasından kaynaklandığı anlașılmaktadır. ${ }^{27}$ Zira nahiv ilmi, nahiv ilminin incelikleri, özellikle Arap gramerinde kullanılan harflerin ne gibi manalar ifade ettiği ve Mettâ b. Yûnus'un zorlandığ birçok konuda usta olan Fârâbî'nin o münazarada olması halinde tartıșma farklı yönde olabilirdi. ${ }^{28}$ Fakat o dönemde Mettâ b. Yûnus ve Sîrâfî arasında gerçekleșen münazara ve bu münazarada ele alınan konuların, İbnü's-Serrâc'tan (öl. 316/929) Arap grameri ve fıkıh gibi dersleri alması hasebiyle mantık ve felsefe alanında önde gelen biri olarak Fârâbî'ye özellikle de öğrencileri tarafından sorulmuş olması kuvvetle muhtemeldir. Nitekim onun bu dönemde telif ettiği eserlerinin birçoğunda özellikle bu gibi soruların cevaplarına odaklandığı ve kafa yorduğu açıkça görülmektedir. Bu bağlamda Fârâbî, o dönem güncel

\footnotetext{
${ }_{23}$ “Sîrâfî mantıkçı Mettâ b. Yûnus ile dil, felsefe ve mantık konularında münazaralar yapmış, bu münazaralarda çok başarılı olmuştur. Mettâ b. Yûnus'la Vezir Ebü'l-Feth İbnü'l-Amîd'in meclisinde yaptığı münazarada (326/938) lafız-mâna ilişkisiyle sözün doğrusunu ve yanlışını belirlemede nahiv ve mantık bilimlerinden hangisinin daha belirleyici olduğu meseleleri tartışılmış, Sîrâfî’nin mantığı, cedel gücü ve üslûp güzelliğiyle gösterdiği başarı orada bulunan herkesi hayrete düşürmüştür. Bu münazarada onun dil ve fıkhı, yani Arap ve İslâm kültürünü, Mettâ b. Yûnus'un da felsefe ve mantığı, dolayısıyla Yunan kültürünü temsil ettiği söylenmiştir. Meydana gelen tartışma, nahivcî ve mantıkçî tartışması olduğu gibi içeriğine binâen kelâm-felsefe ve (yeni ilmin yararları) hakkında yapılan tartışma olarak da zikredilmektedir." (Zülfikar Tüccar, "Sîrâfî “, Türkiye Diyanet Vakfı İslam Ansiklopedisi (İstanbul: TDV Yayınları, 2009), 37/264-265. Ayrıca bkz. Ebû Hayyân Alî b. Muhammed b. Abbâs et-Tevhîdî, el-İmtâ 've'l-mu'ânese, nşr. Ahmed Emîn - Ahmed ez-Zeyn (Beyrut: y.y., 1953), 1/109-128; Mehmet Şirin Çıkar, Nahivciler ile Mantıkçılar Arasındaki Tartışmalar (İstanbul: TDV Yayınları, 2009), 89-115.

24 Çıkar, Nahivciler ile Mantıkçılar Arasındaki Tartışmalar, 115-116; Betül Kıray, "Nahivciler ile Mantıkçılar Arasındaki Tartışmalar" Çanakkale Onsekiz Mart Üniversitesi İlahiyat Fakültesi Dergisi 6(2015), 111.

${ }^{25}$ Tahsin Görgün, "Mettâ b. Yûnus”, Türkiye Diyanet Vakfi İslam Ansiklopedisi (Ankara: TDV Yayınlar1, 2004), 29/417-418.

${ }^{26}$ Çıkar, Nahivciler ile Mantıkçılar Arasındaki Tartışmalar, 116.

${ }^{27}$ Çıkar, Nahivciler ile Mantıkçılar Arasındaki Tartışmalar, 117.

${ }^{28}$ Ebû Hayyân et-Tevhîdî, el-Imtâ 've'l-müânese, 1/108-128.
} 
bir problem olan nahiv ile mantık arasındaki ilișkiyi açıklamaya önem vermiş ve iki disiplini uzlaștırmayı amaçlamıs olmalı ki Kitâbu'l-Hurûf adlı eserinde bu iki ilmin tarihi süreçleri, ifadelerle anlamları arasındaki ilișki ve edatların anlamlarının detaylı analizini; İhṣâ'ü'l-' 'ulûm ve et-Tenbîh 'alâ sebîli's-sa âde adlı eserlerinde epistemolojik yönlerini; el-Elfâzüül-müsta 'mele fi'l-manțk adlı eserinde ise nahiv-mantık ve dil-düsünce arasındaki ilișkiyi uygulamalı bir șekilde ifade etmeye çalıșmıștır. ${ }^{29}$ Özellikle Fârâbî'nin nahiv-mantık ilișkisi üzerine yoğunlașması ve bu konuda ciddi eserler telif etmesi, aslında Mettâ b. Yûnus'un Arap gramerini bilmediği için yanıtlayamadığ 1 Sirâfi'nin sorularına bir yanıt olduğu ileri sürülmekle birlikte, nahivci Sîrâfî'nin, "Mantıkçılar, Arap dilini öğrenmek için çaba göstermiyorlar" iddiasına cevap niteliğinde ve bu iddiayı çürütme gayreti olarak da değerlendirilmektedir. ${ }^{30}$

Mantık-nahiv ilişkisi, mantık tarihinde Hicri üçüncü asrın sonu ile Hicri dördüncü asırdan beri ülemâ ve üdebâ tarafından farklı yöntemlerle Arap İslam kültüründe ele alınmaya çalışılmış ve bu konuda - Sîrâfî ile Mettâ b. Yûnus'da olduğu gibi- ciddi tartışmalar yapılmıştır. Mantık ilmi, Arapçaya tercüme edilip ve Arap âleminde nazarî ilimlerin telifine başlandıktan sonra mantık ile nahiv ilminin mevzu, maksat ve ıstılahat itibariyle ayrı birer sanat olmasına rağmen nahivcilerin, mantık ilminin sanatlarına sokulmasından rahatsız oldukları açıkça anlaşılmaktadır. Aslında İslam kültüründe, "haricî ilimler"le (felsefe ve mantık) bir anlamda Kur'ân'a bağlı bulunan ve Kur'ân'ın tefsirini kolaylaştırdığı düşünülen "geleneksel ilimler" (özellikle nahiv) arasında var olan gizli zıtlı̆̆ın yansıması olarak düşünülmektedir. ${ }^{31}$ Daha açık bir ifadeyle, "tercüme faaliyetlerinin bir sonucu olarak İslâm dünyasına giren mantık ilminin yabancı menşeli olması ve bunu ilk benimseyen kimselerin Müslüman olmayışı, İslâm tarihinin ilk yıllarında nahiv uzmanlarınca kuşkuyla karşılanmasına sebep olmuştur. Nahivci kesimin genel olarak mantık ilmine ihtiyaç olmadığı, zira her dilin gramerine içkin özel mantığı olduğu teziyle noktalanmıştır. "32

\section{Fârâbî'nin Mantık ve Nahiv İlimleri Arasında Kurduğu Analoji ve Onları Sentezlemesi}

Mantık-nahiv zıtlığı veya birinin diğerine üstün olduğu türünden münazaralar yapılmıs ve mantık-nahiv ilișkisi tartışmaları, -daha önceden de ifade edildiği üzere- erken dönem İslam düşüncesinde önemli bir yer edinmiștir. ${ }^{33}$ Arap nahvinin ilk aşamasından son aşamasına kadar onun temelini oluşturan, yasa ve yöntemlerini belirleyen ve bu konuda önemli çalıșmalar gerçekleștiren genelde "acem" olarak isimlendiren Arap olmayan dilcilerin rol oynadığı tarihsel bir gerçektir. Yine zamanla nahiv ilmini kendi çizgisinden çıarıp felsefi yöne kaydıran ve nahiv-mantık ilimlerinin buluşmasından Arap asıllı dilcilerden çok, Ebû Esved ed-Düelî (öl. 69/688), Sîbeveyhi (öl. 180/796), Ali b. Hamza Kisâî (öl. 189/805), Yahyâ b. Ziyâd el-Ferrâ (öl. 207/822) ve Îsâ b. Ömer es-Sekafì (öl. 149/766) gibi dönemin Arap olmayan nahivcilerin etkisi büyük olmuştur. ${ }^{34}$

Kaynaklarda anlaşıldığı kadarıyla mantık ile nahiv ilişkisini ve ortak paydalarını açıklamaya gayret eden ve aralarında bir analoji kuran Fârâbî'den önce veya sonra hiçbir İslâm düșünürü mantıknahiv ilișkisini ve analojisini, onun gibi tafsilatlı bir șekilde ele almamıștır. Onun, İslâm düșüncesinde bu ilişkiyi anlayan ilk kiși olarak görüldüğünü ve bu özelliğinin onun alamet-i fârikası haline geldiğini söyleyebiliriz. ${ }^{35}$ Her ne kadar dilcilerden Sîrâfî ve Ebû Hayyân et-Tevhîdî; mantıkçılardan ise Ebû Süleymân es-Sicistânî (öl. 391/1001) gibi bilginler bu iki ilim arasındaki ilişkiye değinmiş olsalar

\footnotetext{
${ }^{29}$ Ebû Nasr Muhammed b. Muhammed b. Tarhan b. Uzluğ el-Fârâbî, Kitâbu'l-Hurûf, thk. Muhsin Mehdî (Beyrut: Dâru'l- Hurûf, 1986); a.mlf. İhṣâ 'ü'l- 'ulûm, thk. Osman Muhammed Emîn (Kahire: Mektebetu'l-Hancî, 1931); a.mlf. et-Tenbîh 'alâ sebîli's-sa 'âde, thk. Sahbân Halîfât (Amman: Ürdün Üniversitesi, 1987). Ayrıca bkz. Kaya, “Fârâbî”, 12/162-163.

${ }^{30}$ Muhsin Mehdî, Kitâbu'l-Hurûf (mukaddime), 49.

31 Dore, "Fârâbî'nin Gramer-Mantık Analojisinde Nutk", 55; Sadık Türker, "Fârâbî'de Dil-Mantık İlişkisi", Kutadgubilig Felsefe Bilim Araştırmaları 1 (2002), 140-145.

32 Bk. Sadık Türker, " Fârâbî, Mantıkta Kullanılan Lafızlar (Sunuş)", Kutadgubilig, 2 (2002), 103; Ali Durusoy, "Nahiv-Mantık Tartışmaları Bağlamında Sekkâkî'nin Yeri ve Önemi", M.Ü. İlahiyat Fakültesi Dergisi 2/27 (2004), 33-34; Kıray, "Nahivciler ile Mantıkçılar Arasındaki Tartışmalar", 1-2.

33 Mehmet Şirin Çıkar, "Nahiv-Mantık Tartışmalarında Yahya b. Adi'nin Konumu ve "Yunan Mantığı ile Arap Nahvi Arasındaki Fasıllar" Adlı Makalesi", Kutadgubilig Felsefe-Bilim Araştırmaları Dergisi 1/7 (Mart, 2005), 3-12.

${ }^{34}$ Temmâm Hassân, el-Usûl (Kahire: el-Hey'etü'1-Mısriyyetü'1-Âmmetü li'l-Kitâb, 1982), 60vd.; Çıkar, Nahivciler ile Mantıkçılar Arasındaki Tartı̧̧malar, 72.

35 Zeynep Afîfî, Felsefetü'l-luga 'inde'l-Fârâbî (Kahire: Dâru'l-Kabâ', 1997), 197-2012; Kaya, “Fârâbî”,12 /146-148; Çıkar, Nahivciler ile Mantıkçlar Arasındaki Tartışmalar, 117.
} 
da Fârâbî gibi derinlemesine incelememiș ve onun anladığı șekliyle anlayamamıșlardır. Zira dil felsefesi konusu gerek klasik gerek modern dilci ve mantıkçılar açısından en zor konuların başında geldiği Mahmûd Zeydân gibi kişiler tarafından vurgulanmaktadır. ${ }^{36}$

Fârâbî'nin mantık-nahiv arasındaki ilişki ve dille ilgili düșüncelerinde hocası İbnü's-Serrâc'ın büyük etkisi olduğu, bir nevi kendisi, Fârâbî'nin nahiv ilmi ile tanıșmasında bir bağ olduğu kaynaklarda açıkça ifade edilmektedir. Hatta Fârâbî ile İbn Serrâc arasındaki bu ilmi müzakere karșllıklı olmuștur. Fârâbî, İbn Serrâc'dan gramer (nahiv) dersleri alıp bu konuda kendisinden istifade ederken, buna karşılık İbn Serrâc da ondan mantık dersleri almıș ve öğrendiği mantık ilmi savesinde nahiv ilmine yeni bir metot ve yön verme çabasına girmiştir. ${ }^{37}$ Buna karşılık özellikle mantık ilminde Mettâ b. Yûnus ve Harranlı Yuhannâ b. Haylân (öl. 860/920) gibi hocalarını geride bırakan ve mantıknahiv ilminde üstat olan Fârâbî, bu iki ilmin ilișkisini ve yakınlık derecesini derinlemesine zarif bir üslupla açıklamaya ve iki disiplin arasında ilişki kurmaya en çok gayret eden âlimlerin başında gelmektedir.

Mantıksal süreçleri kolaylaștırmada gramere mühim bir rol biçtiği açıça görülen Fârâbî, mantıkla gramer arasında yeni bir ilișki ve benzerlik kurar. Ona göre manalara delalet eden lafızların aksamlarını içeren dil ve nahiv ilmine vakıf olmak, mantık eğitimi ve çalıșmaları için temel etkenlerdendir. ${ }^{38}$ Nahiv ilmi, lafız ve onun manasını incelediği gibi mantık ilmi de lafzî kalıp içinde doğru düșünce ve ilk sabit mana için zorunlu kanun ve kuralları belirler. ${ }^{39}$ Her ne kadar nahiv kanunları ile mantık kanunları birebir aynı olmasa da Fârâbî'nin ifade ettiği gibi net bir șekilde aralarında bir yakınlık, benzeşme, uyum, dolayısıyla analoji bulunmaktadır. Bu anlamda fikrin, dil aracılığıyla aktarılması kanaatine varan Fârâbî, mantık ile gramerin problemleri arasındaki benzerliğin farkına varır ve bu bilim dalının gramer ile akraba olduğunu vurgulamaya çalıșır. Herhangi bir düşünceyi dile getirirken sözlerimizde hataya ve yanlışa düşmemek için belli kurallara mutlaka ihtiyaç duyduğumuzu belirten Fârâbî̀ye göre her iki disiplin de birbirini tamamlayan yasaları verir. Bu noktada onun iki ilim arasında kurduğu bu analojiyi İhṣấ 'ü'l- 'ulûm adlı eserinde açıç̧a şöyle izah etmektedir:

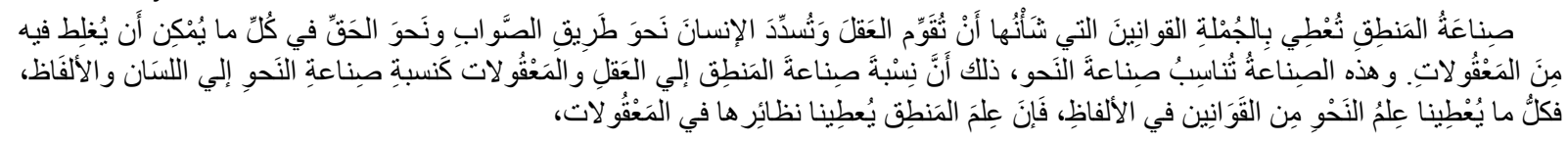

"Mantık sanatı genel olarak, aklı düzelten ve hakkında yanılmanın mümkün olduğu bütün düşüncelerde insanı hakikate ve doğru yola yönelten kanunları verir. Mantık sanatı, nahiv sanatına benzemektedir. Çünkü mantık sanatının aklın algıladı̆̆ı entelektüel objelere münasebeti, nahiv sanatının dile ve sözlere olan nispeti gibidir. Nahiv ilminin sözlerle ilgili olarak bize verdiği bütün kanunların benzerlerini mantık ilmi akılsallarla ilgili olarak bize sağlar." ${ }^{40}$ Başka bir yerde ise Fârâbî aynı șekilde bu iddiasını destekler mahiyetinde, "Bizim gayemiz mantık sanatını araștırmaktır. Mantık aklı, yanlıs yaptığı zaman doğruya sevk eden ve idrakin yardımı ile alınacak herhangi bir sonuca varıldığı zaman bütün yanlıșlıklardan sakındıran bir sanattır. Mantığın idrake münasebeti, gramerin dile münasebeti gibidir. Gramer insanların dilini ıslah etmek ihtiyacından dolayı oluşmuş bir bilim dalıdır. Mantık ise idrakin gerçek olmasını ve yanlıșı önlemek için düșüncenin doğru yönde akıșını sağlar" ifadesiyle iki ilmin arasındaki ortak inceliğinin/analojinin ıslah edici rollerinin olduğunun altını çizer. ${ }^{41}$ Fârâbî'nin, Yunan menșeli "yeni" bilginin alanı tekelleștirmek isteyen Mettâ b. Yûnus'tan farklı olarak, her iki disiplini de daha yüksek bir seviyede birleştirmeyi hedeflemiş olması filozofun düşüncesindeki evrenselci özelliğin bir göstergesi olsa gerektir. ${ }^{42}$

Nahiv ve mantık, mevzuları cihetiyle ortak olmasıyla birlikte mantık ilminin asıl mevzusu kelimelerin ifade ettiği makulâttır. Nahiv ilminin mevzusu ise manalara delalet eden kelimelerdir/lafızlardır. Bundan dolayı mantık, kelimeleri/lafızları genel anlamıyla ele alır, nahiv

\footnotetext{
${ }^{36}$ Mahmûd Zeydân, Fî Felsefeti'l-Luga (Beyrut: Dâru'n-Nahdeti'l-'Arabiyye, 1985).

${ }^{37}$ Muhsin Mehdî, Kitâbu'l-Hurûf (mukaddime), 49; Çıkar, Nahivciler ile Mantıkçılar Arasındaki Tartışmalar, 116.

${ }^{38}$ Fârâbî, el-Elfâzü̈'l-müsta 'mele fi'l-manțkk, thk. Muhsin Mehdî (Beyrut: Dâru'l-Meşrik, 2002), 41-44.

${ }^{39}$ Fârâbî, İhṣ̂ 'ü'l- 'ulûm, 12; Zeynep Afîfî, Felsefetü'l-luga 'inde'l-Fârâbî, 203.

${ }^{40}$ Fârâbî, İhṣ̂a 'ü'l- 'ulûm, 12.

${ }^{41}$ M.M. Hayrullayev, Abu Nasr al-Farabi (Moskova: Nauka, 1982), 149-150; Naile Ağababa, "Farabi ve Dil Bilimi” Gazi Üniversitesi Sosyal Bilimler Dergisi Özel Sayı (2016), 1-9.

${ }^{42}$ Dore, "Fârâbî'nin Gramer-Mantık Analojisinde Nutk", 58.
} 
ilmini ilgilendiren özel yanlarını incelemez. Fârâbî, et-Tenbîh 'alâ sebîli's-sa âde adlı eserinde ise mantıknahiv arasındaki bu ilişkiye ve analojiye dikkat çekerek şöyle der:

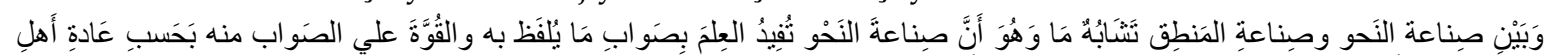

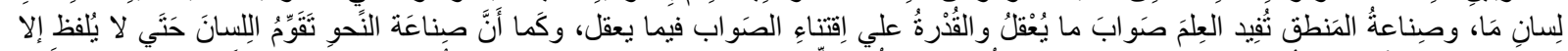

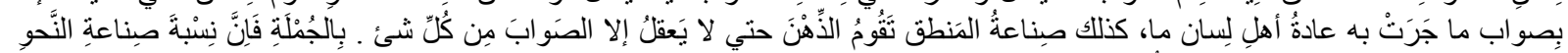

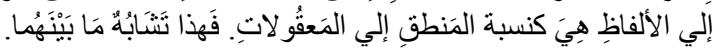

"Nahiv sanatı ile mantık sanatı arasında bir benzerlik vardır ve o da şudur: Nahiv sanatı, herhangi bir toplumun dil kurallarına göre konuşulanın doğru olup olmadığı bilme yetisini ve doğru konuşma becerisini kazandırırken, mantık sanatı ise düşünülenin doğru olup olmadığını bilme ve düşünülenlerde doğru elde etme gücünü kazandırır. Nahiv sanatı, sadece toplumun genel dil kurallarına göre konuşmasını sağlayarak dili düzelttiği gibi mantık sanatı da her düşüncede sadece doğru olanı kavramasını sağlayarak zihni düzeltmektedir. Özetle, dilin lafızlarla olan ilişkisi ne ise mantığın düşüncelerle/ kavramlarla olan ilişkisi de odur. Aralarındaki benzerlik işte tam da budur." 43

Fârâbî, İhṣ̂a 'ü'l- 'ulûm adlı eserinde mantığın gramerle kesișimin ve analojisinin temel noktası, sözlerle ilgili yasaları belirtmesidir. Ancak gramer, yalnızca herhangi bir topluluğa ait olan ifadelerle ilgili iken, mantık bütün toplumların dillerindeki ortak kuralları belirlemekle ondan ayrıldığını açıklamaya çalıșarak mantığın nahiv ilmine kıyasla evrensel olduğu yönündeki bu fikrini daha olgun bir şekilde şöyle izah eder:

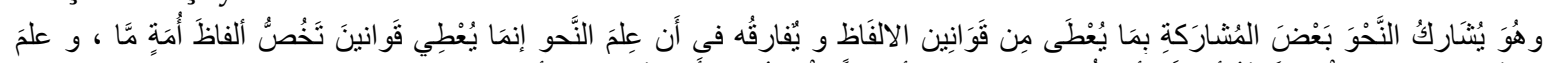

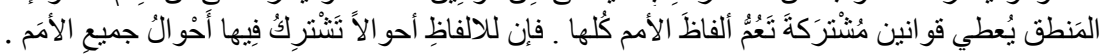

“Mantık, kelimelerin (lafız) kanunlarını vermesi bakımından bir dereceye kadar, nahiv ile birleșir. Nahiv ilminin herhangi bir halkın (ümmet) diline mahsus olan kuralları ortaya koymasına karşılık, mantık ilmi bütün milletlerin kelimelerini içine alan müșterek kanunları vermek bakımından ondan ayrılır. Çünkü kelimelerde öyle haller vardır ki, bütün halklar, bunda müșterektir." ${ }^{44}$ Fârâbî'nin mantığı gramere benzettiği temel nokta, sözlerle ilgili yasaları belirtmesidir. Ancak gramer, yalnızca herhangi bir topluluğa ait olan ifadelerle ilgili iken, mantık bütün toplumların dillerindeki ortak kuralları belirlemekle ondan ayrilır.

Aslında Fârâbî, gramer bakımından hemen hemen her toplumda var olan bazı ortak özelliklerin mevcudiyetinden söz ettiği gibi herhangi bir dilde bulunup da başkasında bulunmayan özelliklerin varlığına da dikkat çeker. Bu bağlamda meselâ; kelimelerden bazılarının müșterek ve mürekkeb olması; müfred kelimelerin ise isim, fiil, harf veya edat olarak gelmesi gibi özellikler hemen hemen bütün toplumlarda ortak özelliklerdir. Fakat nahiv ilminde/dilbilgisinde bazı kanunlar ise sadece bir topluma ait hususiyetlerdir. Örneğin fâilin/öznenin merfu, mef'ûlun bihinin mansub ve muzafun ileyhin mecrûr olması veya muzafun ileyhin elif lâm takısı almaması gibi birçok özellik sadece Arap diline has kurallardır. Ancak nahiv ilminde bulunup da bütün toplumların kelimelerinde ortak olan şeylerin var olması kaideyi bozmaz. Çünkü nahivciler, nahvi tespit ederken bu dilde mevcut olması dolayısı ile o kanunları ele almışlardır. Meselâ; Arap nahivcilerin/dilbilimcilerin "Arapçada kelime çeşitleri isim, fiil ve edattır (harftir)" demelerinin yanı sıra Yunan nahivcilerinin de "Yunancada cümlenin parçaları isim, kelime ve edattır" demeleri şu anlama gelmez: "bu taksim, sadece Arapçada veya sadece Yunancada bulunur", bilâkis bu özelik bütün dillerde bulunur. Arap nahivcileri onu Arap dilinin bir gerçeği ve bu dilin yapısında bulunduğu ciheti ve gerçeği ile ele almışlarken; Yunan dilbilimcileri de onu Yunancada bulunduğu için ele almışlardır. Dolayısıyla her toplumun nahvi/dil kuralları, gerek sadece o topluma ait gerek kendi toplumuyla ve başka toplumlarla müşterek olan kurallarını kendi yapısında bulunduğu cihetiyle inceler. ${ }^{45}$

İşte nahivciler ile mantıkçıların kelimelere ve lafızlara bakışları arasındaki net fark budur. Yani nahiv ilmi, kelime ve lafızları o toplumu ilgilendirdiği şekliyle ele alıp kendisine özel yasalar koyarken, mantık ilmi kelime ve lafızları tüm toplumları ilgilendirecek bakış açısıyla ele alır ve genel kanunlar koymaya çalışır. Bundan dolayı Fârâbi'ye göre nahiv/dilbilgisi sadece bir toplumun lafızlarına özgü yasaları vermesine karşılık, mantık bilimi tüm toplumların lafızlarını içeren ortak yasaları belirler. Herhangi bir doğal dilin grameri, ona kültürel olarak bağlıken, mantık ilmi evrenseldir ve aslında bütün insani düşüncesinin altında yatmaktadır. Bu bağlamda nahiv ilmi has,

\footnotetext{
${ }^{43}$ Fârâbî, et-Tenbîh 'alâ sebîli's-sa 'âde, 230-231; M.M. Hayrullayev, Abu Nasr al-Farabi, 149-150.

${ }^{44}$ Fârâbî, İhṣ̂a 'ü'l- 'ulûm, 18.

${ }^{45}$ Fârâbî, İhṣâ' ü̉'l- 'ulûm, 18.
} 
mantık ilmi ise daha genel ve evrenseldir. Ancak ikisinin de ortak paydası kelime ve lafızlardır. Nahiv ilmi, kelime ve lafızların yapısı, kelimenin cümle içindeki konumu ve son harekesinin nasıl olacağı gibi özelliklerini incelerken, mantık ilmi, doğru fikir ve ilk sâbit manaya delalet etmesi cihetiyle kelime ve lafızları ele alır. Kısaca aralarındaki fark şöyle özetlenebilir: mantıkî delâletlerine göre yapılan sınıflandırma, lafızları manaya tâbi kılarken, gramatik etkilere göre yapılan sınıflandırma ise manaları lafza tâbi kılar. ${ }^{46}$ Nahiv ilmi dilsel ifadeyle ilgilenirken, mantık ilmi ise daha çok düşünce ve lafızların ifade ettiği manayla ilgilendiği vurgulanmaktadır. ${ }^{47}$

Fârâbî'nin lafızları belirlemedeki amacı, Arapça ve diğer dillerde bulunan lafızları sınıflandırıp sunmakla alâkalı değil bilâkis, başka bir alanda yeni ufuklar açmak ve mantığa bir giriş yapmaktır. Bu alan ise lafızların gramatik etkilerinden değil, mantıkî delâletlerine göre sınıflandırıldığı alandır. Zira Fârâbî ile beraber felsefi dil bağımsızlaşmış, lafızlar ve lafızların içerdiği manalar netleşmiştir. ${ }^{48}$

İki ilim arasındaki benzerlik ve farklılıkları ortaya koyan Fârâbî, el-Elfâzü̈'l-müsta 'mele fi'l-manțk adlı eserinin nihayetinde ise mantık-nahiv sanatlarını karşılaştırarak şöyle bir sonuca varır:

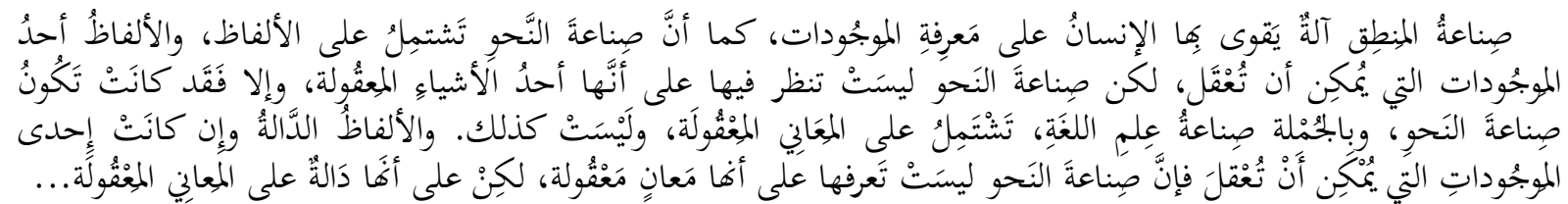

"Nahiv sanatı, lafızları içerdiği, lafızların ise akledilebilir varlıklardan biri olduğu gibi, mantık sanatı da insanın kendisiyle varlıkları tanıma gücü /zihinsel bir donanıma sahip olmasını kazandığı bir alettir. Fakat nahiv sanatına bir düşünce disiplini olarak bakılmaz. Yoksa mantık, bizzat nahiv sanatının kendisi olurdu. Ezcümle, dilbilim/nahiv sanatı, manaları içerdiği halde bizzat manaların kendisi değildir. Bir manaya delalet eden lafızlar her ne kadar akledilebilir varlıklardan olsa da nahiv ilmi onları akledilebilir anlamlar olarak değil bilakis akledilebilir anlamlara delalet eden olarak tanımlamaktadır." ${ }^{49}$ Buradan hareketle Fârâbî, iki bilim dalını karşılaştırarak mantığı "varlıkları tanıma hususunda insanın, kendisiyle geliştiği/yetiştiği bir alet ilmi" olarak tanımlar. Nahiv ilmi ise lafızları kapsar ve bu lafızlar ise akılla kavranılması mümkün olan varlıklardan birisidir. Ancak nahiv ilminin kendisi, bir ilim olarak, kendisiyle akılla kavranan şeylerin incelendiği bir ilim değildir. Nahiv ilmi (ve esasında dil ilimlerinin tamamı), akılla kavranabilen manaları kapsamına almış ve bunlar üzerine inceleme yapmıştır (yani bugüne kadar böyle olmuştur). Fakat nahiv ilminin kapsamı, sadece bunlarla sınırlı değildir. Manaya delalet eden lafızlar, her ne kadar akılla kavranılması mümkün olan varlıklardan olsalar da, nahiv ilmi; bunları "akılla kavranan manalar" olarak değil, "akılla kavranan manaların delaletleri (işaretleri/sembolleri)" olarak inceleyen bir ilimdir. "Fârâbî, hem nahiv hem de mantık kurallarına uyan dilin, akledilir anlamlarla bir münasebetinin olduğunu ve bu bağlamda ifadelerin dilde birleşme şekliyle anlamlarının zihinde birleşmesinin aynı biçimde gerçekleştiğini savunur." 50

Dolayısıyla Yahyâ b. Adî (öl. 364/975) ve Ebû Süleymân Sicistânî gibi âlimlerin mantığın nahiv ilmine üstünlüğünü iddia etseler de Fârâbî nahiv ve mantık ilișkisine daha 1lımlı bir yaklașım sergiler. Bu iki ilim arasında analoji kurmaya çalışır. Daha açık bir deyișle, ikisi arasındaki benzerlik veya benzerliklerinden hareket ederek biri için dile getirdiğini diğeri için de söz konusu olduğunu izah etmeye çalışır ve her iki ilim dalını yeni bir formatta bulușturmaya / sentezlenmeye gayret eder. ${ }^{51}$ Zira nahiv sanatı, manaya delalet eden lafızları kapsadığı ve incelediği ciheti ile düşünüldüğünde, daha çok mana açısından lafız üzerine odaklanan mantık sanatının anlașılması bakımından yeteri miktarda nahiv ilmini bilmenin daha faydalı olunacağı düșünülmektedir. Zira Fârâbî, dil ve nahiv ilmine vâkıf olmayı özellikle mantık ilmine bașlamasında ve mantık öğretimini kolaylaștırmasında önemli bir yer işgal ettiğini ve mantık için temel/ bir ön hazırlık/girizgâh mahiyetinde olduğu kanaatindedir. ${ }^{52} \mathrm{Bu}$ bağlamda mantık bilimi ile nahiv bilimi işlevleri açısından birbirine karışması söz konusu değildir.

\footnotetext{
${ }^{46}$ Fârâbî, İhṣ̂a'ü'l-'ulûm, 18-19; ; Zeynep Afîfî, Felsefetü'l-luga 'inde'l-Fârâbî, 67; Çıkar, Nahivciler ile Mantıkçılar Arasındaki Tartışmalar, 120.

${ }^{47}$ Zeynep Afîfî, Felsefetü'l-luga 'inde'l-Fârâbî, 210; Çıkar, Nahivciler ile Mantıkçılar Arasındaki Tartışmalar, 123.

${ }^{48}$ Cihâmî, Cîrâr, el-İskâliyetü'l-lugaviyye fi'l-felsefeti'l-Arabiyye (Beyrut: Dârü'l-Meşrik, 1994), 87.

${ }^{49}$ Fârâbî, el-Elfâzü̈'l-müsta 'mele fi'l-manțk, 107.

${ }^{50}$ Mirpenç. Fârâbî'de Mantığın Dili ve Dilin Mantığı Üzerine Bir Anlam Arayışı, 176.

${ }^{51}$ Musa Yıldız, "Fârâbî'de Dil-Mantık ve Kültür İlişkisi” Felsefe ve Sosyal Bilimler Dergisi, 14(Haziran, 2012), 113.

52 Fârâbî, et-Tenbîh 'alâ sebîli's-sa 'âde, 232-233.
} 
Bunlar, birbirine karşıt değil, bilâkis uyumludur. "Bu açıdan bakıldığında Fârâbî'nin özellikle bilimler sınıflandırmasında ilimleri; dil, mantık, matematik, tabiat-ilâhiyat ve medenî ilimler şeklinde beş sınıfa ayırıp nahiv ilmini ilk sıraya yerleştirmesi ilgi çekicidir..$^{53}$

Fakat şu bir gerçek ki, Fârâbî'nin bilimlerin başına nahvi yerleştirmesi, gramercilerin iddia ettiği gibi Kur'ân-1 Kerîm'i daha doğru anlamakla alakalı değil, onu mantığa en uygun giriş olarak görmesiyle ilgilidir. Bu bakımdan Fârâbî, Helenistik felsefeden farklı olarak mantığa giriş için İsâgûcî'nin yerine nahvi koyar. ${ }^{54}$ Ancak nahiv ilminde aynı toplumun farklı sanat dallarında ilgilenen kimselerin aynı kelimeleri farklı anlamlarda kullanabildiği göz önüne alınırsa, gramatik konuların bu dilde halkın kullandığı anlamlarla sinırlı olduğu ve tüm toplumlar için ortak bir kültür evreni sunmada yetersiz olduğu söylenilebilir. ${ }^{55}$ Bundan dolayı tüm toplumlar için anlam birliği sağlayan temel ölçüt olarak nahiv ilmi değil, mantık ilmi olduğu söylenebilir. Bu açıdan Fârâbî'ye göre tüm toplumların kültürel etkinliklerini düzenleyen felsefî düzey, ancak mantık ilimi aracığıyla oluşturulabilir. ${ }^{56}$

Fârâbî'nin mantık sanatı ile nahiv sanatı arasında kurduğu bu yakın ilişki ve bunlar hakkındaki bilimsel düşünceleri, daha sonra İslâm kültür dünyasında gerek mantıkçılar gerekse nahivciler üzerindeki etkisi açıkça görülmektedir. Öyle ki 12. yüzyıldan sonra İslam kültüründe mantık çalışmaları, nahiv çalışmalarının da önüne geçmiştir. Böylece Sîbeveyh'den itibaren gerek nahivciler gerek diğer İslâm ülemâ ve üdebânın mantık ilmine yönelik olumsuz bakış açılarını genel anlamda olumlu yönünde etkilemiş ve onların gözlerini, zihinlerinde kurdukları dünyadan farklı bir âleme açılmasına vesile olmuştur. Doğal olarak, yaşanan bu sürecin her iki disiplin açısından da olumlu sonuçları olduğu söylenebilir. Mantıkçıların özellikle, Fârâbî’den itibaren dil ilimlerine daha yakın bir alaka gösterip mantık kitaplarında "mebâhisü'l-elfâz" konusuna yer verilmesi ve nahivcilerin de mantıktan etkilenerek gramer ile ilgili çalışmalarında -büyük nahiv bilgini İbnü's-Serâc'ın Kitâbu'lUsûl fi'n-nahv adlı eserinde olduğu gibi- mantık ilmine ait tasnif ve bölümleri kullanmaları bu olumlu etkileşimin açık işaretidir. ${ }^{57}$

\section{SONUÇ}

Fârâbî, Meșsâi felsefesini sistemleștirmesi, “İkinci Öğretmen” (Muallim-i Sânî) lakabıyla anılması ve İslâm âleminin önde gelen filozoflarından biri olarak addedilmesinin yanı sıra, mantık ve nahiv ilimleri arasında bir analoji kuracak seviyede Arap gramerinin inceliklerini de iyi bilen, üretken ve çok yönlü bir bilgedir. Tercüme faaliyeti ile birlikte mantık ve felsefe gibi antik döneme ait ilimlerin Arapçaya çevrilmesine paralel olarak bazı kimseler tarafından özellikle de Arap dilbilimcileri tarafından mantık ilmi yoğun eleștiriye tabi tutulmuș ve bu hususta hararetli tartışmalar yapılmıștır. Özellikle bu konuda dönüm noktası olarak görülen Mantıkçı Mettâ b. Yûnus ile Arap dilbilimcisi Sirâfi arasında Büveyhî veziri İbn Furât'ın sarayında cereyan eden tartıșma çok ses getirmiștir. İki bilgin arasında geçen tartışmadan sonra, dil ve mantık ilișkisi, mantığı eleștirenler bașta olmak üzere, nahivcileri eleștirenler ve Fârâbî gibi bir senteze varmak isteyenler olarak varlığını devam ettirmiștir. Hatta Fârâbî, mantık ile nahiv sanatları arasındaki farklılıkları ve benzerlikleri ortaya koyan ilk İslâm filozofu olarak ortaya çıkmıştır, diyebiliriz.

Fârâbî, mantık-nahiv ilișkisini ve analojisini ele alırken çağının nahivcilerinden ve mantıkçlarından farklı bir tarzda, meseleyi felsefî bir açıdan ele alarak incelemis ve bu konuda farklı bir anlayıș geliștirmiștir. Fârâbî'nin, eserlerini Arapça telif etmekle birlikte, Arap dilbilgisinin (nahiv) sorunlarının ötesinde evrensel bir dilbilim anlayışı geliștirdiği söylenebilir. Zira Arap nahvinin/gramerinin ortaya çıkışını genel anlamda nahivcilerin, lahn (hatalı konuşma) sonucuna bağlamasına karşılık, Fârâbî, dilin ortaya çıkıșı ve gelișiminin toplumsal bir temelden hareketle zaruri ihtiyaç ve Arap kültürünün bir gereksinimi olarak görür. Fârâbî, mantık ilminin, nahiv ilminin ortaya çıkmasında ve șekillenmesinde bir etkisi olmasa da nahiv/dil ile mantık arasında yakın benzerlik ve sıkı ilişki bulunduğu hususu üzerinde önemle durmuștur. $O$, mantıkla nahvi farklı yönlere sahip bağımsız iki sanat hatta birbirini tamamlayan iki bilim dalı olarak görmektedir.

\footnotetext{
${ }^{53}$ Fârâbî, İhṣấ' 'ü'l- 'ulûm, 2.

${ }^{54}$ Yıldız, "Fârâbî’de Dil-Mantık ve Kültür İlişkisi" , 96.

${ }^{55}$ Fârâbî Kitâbü'l-Elfâzı'l-Müsta'meleti fi'l-Mantık, thh. Muhsin Mahdî (Beyrut: Dar'ül- Meşrik, 1968), 41-43.

${ }^{56}$ Yıldız, "Fârâbî'de Dil-Mantık ve Kültür İlişkisi" , 113-116.

${ }^{57}$ Muhammed Âbid el-Câbirî, Arap İslam Kültürünün Akıl Yapısı, çev. Burhan Köroğlu vd. (İstanbul: Kitabevi Yay., 1999), 28, 539; Emiroğlu, "Mantık", 28/18.
} 
Nahiv, konuşmada yanlış yapmanın mümkün olduğu durumlarda dili yanlıştan koruması, mantık ise soyut ve küllî mefhumları kavramada zihnin hataya düşmesini önlemesi ve bunun için evrensel yasalar ortaya koyması gibi yönlerden, ikisi arasındaki analojiyi ifade etmektedir. Bununla birlikte mantık herhangi bir zaman, yer ve dil farkı gözetmeksizin insan düşüncesine mahsus olan evrensel yasalar ve bu düşünceye delâlet eden ifadeler manzumesi iken, nahiv/gramer ise sadece belirli bir dile mahsus olan özel kurallar manzumesidir.

Bu bağlamda Fârâbî, mantık-nahiv arasındaki ilişkiyi mantık ilminin lafız ve kelimelerle ilgili genel yasaları vermesi ve nahiv ilminin özel yasaları ortaya koyması bakımından umum-husus cihetiyle ele almaktadır. Özellikle tefsir, hadis ve felsefe gibi birçok ilimde olduğu gibi mantık ilminin de anlaşılması için nahiv ilmi eğitiminin gerekli olduğunu vurgulamakta ve ikisi arasında bazı farklılıklar dolayısıyla tam bir özdeşlik olmasa da aralarında sağlam bir ilişki olduğunu savunmaktadır. Dolayısıyla nahivcilerle mantıkçılar arasında gerçekleşen tartışmalar ve Fârâbî'nin bu konudaki uzlaştırıcı çabası her iki alanın hedefini, fonksiyonunu ve aralarındaki ilişkiyi görme açısından faydalı olmuş; genel anlamda nahivcilerin mantık ilmine olan olumsuz bakış açılarını, olumlu olarak etkilemiştir.

KAYNAKÇA

Abdulhamid Ömer, Ahmed Muhtar. Mu'cemu'l-Luğati'l-Arabiyyeti'l-Muâsıra. Beyrut: Âlemü'l-Kütüb, 2008.

Abdül'âl Sâlim Mukrem, el-Halkatü'l-mefkude fì târîhi'n-nahvi'l-Arabî. Beyrut: Müessesetü'r-Risâle, 1993.

Afîfî, Zeynep. Felsefetü'l-luga 'inde'l-Fârâbî. Kahire: Dâru'l-Kabâ', 1997.

Afnan, Soheil M. Philosophical Terminology in Arabic and Persian. Leiden: E. J. Brill, 1964.

Ağababa, Naile. “Farabi ve Dil Bilimi”. Gazi Üniversitesi Sosyal Bilimler Dergisi Özel Sayı (2016), 1-9.

Ahmed Emîn b. İbrâhîm et-Tabbâh. Duha'l-İslâm. Kahire: y.y., 1933.

Akşit, Mirpenç. "Fârâbî Düşüncesinde Mantığın Dili ve Anlamı". Uluslararası Sosyal Araştırmalar Dergisi 11/56 (Nisan 2018), 244-248.

Akşit, Mirpenç. Fârâbî'de Mantığın Dili ve Dilin Mantı̆̆ı Üzerine Bir Anlam Arayışı. Erzurum: Atatürk Üniversitesi, Sosyal Bilimler Enstitüsü, Doktora Tezi, 2017.

Anthony Robert Booth. Analitik İslam Felsefesi. çev. Emel Sünter- Mirpenç Akşit. Konya: Eğitim Yayınları, 2020.

Aydın, İbrahim Hakkı. Farabi'de Metafizik Düşünce. İstanbul: Bil Yayınları, 2000.

Ayık, Hasan, "Felsefi Kavramların Oluşmasında Farabî'nin Rolü", Gazi Üniversitesi Çorum İlahiyat Fakültesi Dergisi 4/7 (2005), 77-94.

Beyhakī Zahîrüddîn, Ebü'l-Hasen Alî b. Zeyd b. Muhammed. Târîhu hükemâ'i'l-İslâm. thk. Muhammed Kürd Ali. Dımaşk: y.y., 1946.

Boer, T.J. De. İslam'da Felsefe Tarihi. çev. Yaşar Kutluay. İstanbul: Anka Yayınları, 4. Basım, 2004.

Câbirî, Muhammed Âbid. Arap İslam Kültürünün Akıl Yapısı. çev. Burhan Köroğlu vd. İstanbul: Kitabevi Yayınları, 1999.

Cevherî, Ebû Nasr İsmâîl b. Hammâd. Tâcü'l-lugga. thk. Ahmed Abdulğafûr Attâr. 40 Cilt. Beyrut: Dâru'l-'İlmi lil-Melâyîn, 4. Basım, 1987.

Cihâmî, Cîrâr. el-İskâliyetü'l-lugaviyye fi'l-felsefeti'l-Arabiyye. Beyrut: Dârü'l-Meşrik, 1994.

Çıkar, Mehmet Şirin. “Nahiv-Mantık Tartışmalarında Yahya B. Adi'nin Konumu ve 'Yunan Mantığı ile Arap Nahvi Arasındaki Fasıllar' Adlı Makalesi". Kutadgubilig Felsefe-Bilim Araştırmaları Dergisi, 1/7 (Mart, 2005), 66-76.

Çıkar, Mehmet Şirin. Nahivciler ile Mantıkçılar Arasındaki Tartışmalar. İstanbul: TDV Yayınları, 2009.

Dayf, Şevki. el-Medârisü'n-nahviyye. Kahire: Dârü'l-Ma'ârif, 7. Basım,1968. 
Dore, Fatma. "Fârâbî'nin Gramer-Mantık Analojisinde Nutk". ETHOS: Felsefe ve Toplumsal Bilimlerde Diyaloglar 12/1 (2019), 52-72.

Durusoy, Ali. “Nahiv-Mantık Tartışmaları Bağlamında Sekkâkî'nin Yeri ve Önemi”, M.Ü. İlahiyat Fakültesi Dergisi 2/27 (2004), 25-39.

Efgânî, Saîd. Min Târîhi'n-nahv. Beyrut: Dârü'l-Fikr, 1978.

Emiroğlu, İbrahim. "Mantık". Türkiye Diyanet Vakfı İslam Ansiklopedisi. 28/18-28. Ankara: TDV Yayınları, 2003.

Emiroğlu, İbrahim. Klasik Mantığa Giriş. Ankara: Elis Yayınları, 2010.

Erdoğan, İsmail. “Bazı Felsefi Kavramlara Divan-1 Lügati't-Türk'ten Karşılık Olabilecek Terim Örnekleri". Fırat Üniversitesi İlahiyat Fakültesi Dergisi 17/1 ( 2012), 19-26.

Fârâbî, Ebû Nasr Muhammed b. Muhammed b. Tarhan b. Uzluğ. Kitâbu'l-Hurûf. çev. Ömer Türker İstanbul: Litera Yayıncılık, 2008.

Fârâbî, Ebû Nasr Muhammed b. Muhammed b. Tarhan b. Uzluğ. el-Elfâzü̈l-müsta 'mele fi'l-manțtk. 2. Basım. thk. Muhsin Mehdî. Beyrut: Dâru'l-Meşrik, 2002.

Fârâbî, Ebû Nasr Muhammed b. Muhammed b. Tarhan b. Uzluğ. et-Tenbîh 'alâ sebîli's-sa 'âde. thk. Sahbân Halîfât. Amman: Ürdün Üniversitesi, 1987.

Fârâbî, Ebû Nasr Muhammed b. Muhammed b. Tarhan b. Uzluğ. İhṣ̂a 'ü'l- 'ulûm. thk. Osman Muhammed Emîn. Kahire: Mektebetu'l-Hancî, 1350/1931.

Fârâbî, Ebû Nasr Muhammed b. Muhammed b. Tarhan b. Uzluğ. Kitâbu'l- Hurûf. thk. Muhsin Mehdî. Beyrut: Dâru'l-Ḥurûf, 1986.

Fârâbî, Ebû Nasr Muhammed b. Muhammed b. Tarhan b. Uzluğ. Kitâbü'l-Elfâzı'l-Müsta'meleti fi'lMantık, thh. Muhsin Mahdî. Beyrut: Dar'ül- Meşrik, 1968.

Feriedrich, Dieterici. Alf Arabis Philosophische Abhandlungen. Leiden: E.J. Brill, 1890), 115-118.

Filiz, Şahin. "İslam Rönesansı Ya Da Farabicilik Çağ'ını Açan Türk Filozofu Farabi”. Muallim-i Sân̂ิ Uzlukluoğlu Fârâb̂̂, ed. Enver Demirpolat-Rahime Çelik. İstanbul: Kitap Dünyası, 2020.

Filiz, Şahin. Fârâbî. İstanbul: İnsan Yayınları, 2005.

Fîrûzâbâdî, Ebü't-Tâhir Mecdüddîn Muhammed b. Ya'kūb b. Muhammed. el-Kāmûüü'l-muhịt. 8.Basım. Beyrut: Mektebetu't-Tahkîk ve't-Turâs fî Müessesetü'r-Risâle, 2005.

Gerhard Endress, “el-Münâzaratü beyne'l-mantıkı'l-felsefî ve'n-nahvi'l-Arabî fi usûri'l-hulefâ". Mecelletü târîhi'l-ulûmi'l-Arabiyye. 1/2, Halep 1997.

Görgün, Tahsin. "Mettâ b. Yûnus", Türkiye Diyanet Vakfı İslam Ansiklopedisi. 29/417-418. Ankara: TDV Yayınları, 2004.

Hayrullayev, M.M. Abu Nasr al-Farabi. Moskova: Nauka, 1982.

İbn Ebû Usaybia, 'Uyûnü'l-enbâ' fi tabakātị'l-ețibbâ. thk. Nizâr Rızâ. Beyrut: y.y., 1965.

İbn Hallikân, Ebü'l-Abbâs Şemsüddîn Ahmed b. Muhammed b. İbrâhîm b. Ebî Bekr el-Bermekî elİrbilî. Vefeyâtü'l-a yân ve enbâ'ü ebnâ'i'z-zamân. thk. İhsân Abbâs. Beyrut: Dâru Ṣadr, 1397/1977.

İbnü'l-Enbârî Ebü'l-Berekât, Kemâlüddîn Abdurrahmân b. Muhammed b. Ubeydillâh. Nüzhetü'lelibbâ' fì tabakāti'l-ü̈ebâ'’. nşr. İbrâhim es-Sâmerrâî. Ürdün: Mektebetü'l-Menâr, 1405/1985.

İbnü'l-Kıftî, Ebü'l-Hasen Cemâlüddîn Alî b. Yûsuf b. İbrâhîm b. Abdilvâhid eş-Şeybânî. İnbâhü'r-ruvât alâ enbâi'n-nuhât, nşr. M. Ebü'l-Fazl İbrâhim. 4 Cilt. Kahire: Dârü'l-Kütübi'l-Mısriyye, 1406/1995.

İbnü'l-Kıftî, Ebü'l-Hasen Cemâlüddîn Alî b. Yûsuf b. İbrâhîm b. Abdilvâhid eş-Şeybânî. İhbârü'l'ulemâ' bi-ahbâri'l-hükemâ, thk. İbrahîm Şemsuddîn. Beyrut: Dâru Kütübi'l-İlmiyye, 1426/2005. 
İbnü'l-Manzûr, Ebü'l-Fazl Cemâlüddîn Muhammed b. Mükerrem b. Alî b. Ahmed el-Ensârî erRüveyfiî. Lisânu'l-'Arab. 15 Cilt. Beyrut: Dâru Șadr, 3. Basım, 1414/1993.

İbnü'n-Nedîm, Ebü'l-Ferec Muhammed b. Ebî Ya'kūb İshâk b. Muhammed b. İshâk. el-Fihrist. thk. İbrâhim Ramadân. Beyrut: Dâru'1-Ma 'rife, 1417/1997.

Kaya, Mahmut. "Fârâbî", Türkiye Diyanet Vakfi İslam Ansiklopedisi. 12/162-163. İstanbul: TDV Yayınları, 1995,

Kazvinî, Ebü'l-Hasen Necmüddîn Debîrân Alî b. Ömer b. Alî el-Kâtibî. er-Risâletü'ş-şemsiyye fi'lk avâ’ idi'l-manț ık ryye. thk. Mehdî Fazlüllâh. Beyrut: Merkezü's-Sekafi'l-Arabî, 1998.

Kıray, Betül. "Nahivciler ile Mantıkçılar Arasındaki Tartışmalar". Çanakkale On sekiz Mart Üniversitesi İlahiyat Fakültesi Dergisi 6(2015), 105-114.

Kurtubî, Ebü'l-Kāsım Sâid b. Ahmed b. Abdirrahmân el-Endelüsî. Țabakātü̈l-ümem. thk. Luvîs Şeyho. Beyrut: y.y., 1913.

Mâzin el-Mübârek. en-Nahvü'l-Arabî el-'illetü'n-nahviyye: Nes'etühâ ve tetavvürühâ. Beyrut: Dârü'l-Fikr, 1981.

Muhammed Muhtâr, Veledu Ebbâh. Tarihu'n-Nahvi'l-Arabiyyi fi'l-Meşrik ve'l-Meğrib. Beyrut: Dâru Kütübi'l-i̇lmiyye, 1971.

Râzî el-Kazvînî, Ebü'l-Hüseyn Ahmed b. Fâris b. Zekeriyyâ b. Muhammed el-Hemedânî. Mu'cemü mekāyîisi'l-luğa. Beyrut: y.y., ts.

Râzî, Ebû Abdillâh Zeynüddîn Muhammed b. Ebî Bekr b. Abdilkādir. Muhtârü'ș-Sihhâh. thk. Yusuf Şeyh Muhammed. Beyrut: Daru Numuziciyye, 1999.

Râzî, Kutbüddîn. Şerḥu'ş-Şemsiyye. İstanbul: y.y. 1288.

Safedî, Ebü's-Safâ (Ebû Saîd) Salâhuddîn Halîl b. İzziddîn Aybeg b. Abdillâh. el-Vâfí bi'l-vefeyât. thk. Ahmed Arnavud-Türki Mustafa. 29 Cilt. Beyrut: Dâru İhyâi'l-Turasi'l- Arabî, 1420/2000.

Safedî, Ebü's-Safâ (Ebû Saîd) Salâhuddîn Halîl b. İzziddîn Aybeg b. Abdillâh. el-Vâfí bi'l-vefeyât. thk. Ahmed Arnâut- Türkî Mustafâ. Beyrut: Dâru ihyâi't-Türâs, 1420/2000.

Sâid el-Endelüsî, Ebü'l-Kāsım Sâid b. Ahmed b. Abdirrahmân el-Endelüsî el-Kurtubî et-Tuleytılî. Tabakātü'l-ümem. çev. Ramazan Şeşen. İstanbul: Türkiye Yazma Eserler Kurumu Başkanlı̆̆ı, Yayınları, 2014, 148-150.

Sedâd, Ali. Mîzânü'l-'ukûl fi'l-mantık ve'l-usûl. İstanbul: y.y., 1303.

Seyyîd Şerf el-Cürcânî, Ebü'l-Hasen Alî b. Muhammed b. Alî el-Hanefî. Mu'cemu't-ta 'rîfât, thk. Muhammed Sıddık Minşâvî. Kahire: Dâru'l-Fâḍila, ts.

Sezgin, Fuat. Târîhu't-Turâsi'l-Arabî. çev. Mahmûd Fehmî Hicâzî. Riyad: İdâretu's-Sekâfe ve'n-Naşr Câmiatu İmâm Muhammed b. Suûd el-İslâmiyye, 1991.

Sîrâfî, Ebû Saîd el-Hasen b. Abdillâh b. Merzübân. Ahbârü'n-nahviyyîne'l-Basriyyîn. nşr. Muhammed İbrâhîm el-Bennâ. Kahire: Dârü'l-I'tisâm, 1374/1985.

Şâtır, Muhammed Ahmed Muhammed. el-Mûciz fì Neş'eti'n-Nahv. Kahire: Mektebetü'l-Külliyati'lEzheriyye, 1983.

Şemsüddîn, Ahmed. el-'Alâm mine'l-felâsife. Beyrut: Dâru Kütübi'l-'Illmiyye, 1411/1990.

Tantâvî, Muhammed. Nes'etü'n-nahv ve târîhu eşheri'n-nuhât. Kahire: Dârü'1-Menâr, 1991.

Tehânevî, Muhammed Ali. Mevsû́atu keşşâfi ıstılâhâti'l-funûn ve'l-'ulûm. Beyrut: Mektebetü'l-Lubnan, 996.

Temmâm Hassân, el-Usûl. Kahire: el-Hey'etü'l-Misriyyetü'l-Âmmetü li'l-Kitâb, 1982.

Tevhîdî, Ebû Hayyân Alî b. Muhammed b. Abbâs. el-İmtâ‘ ve'l-mu'ânese. nşr. Ahmed Emîn -Ahmed ez-Zeyn. 3 Cilt. Beyrut: el-Mektebetu'1-'Asriyye, 1373/1953. 
Tüccar, Zülfikar. "Sîrâfî" Türkiye Diyanet Vakfı İslam Ansiklopedisi. 37/264-265. İstanbul: TDV Yayınları, 2009.

Türker, Sadık. "Fârâbî, Mantıkta Kullanılan Lafızlar (Sunuş ve Çeviri Hakkında)". Kutadgubilig FelsefeBilim Araştırmaları, 2 (2002), 93-178

Türker, Sadık. "Fârâbî' de Dil-Mantık İlişkisi". Kutadgubilig Felsefe-Bilim Araştırmalar 1 (2002), 140-145.

Yıldız, Musa. "Fârâbî’de Dil-Mantık ve Kültür İlişkisi” Felsefe ve Sosyal Bilimler Dergisi, 14 (Haziran, 2012), 94-120.

Zebîdî, Ebü'l-Feyz Muhammed el-Murtazâ b. Muhammed b. Muhammed b. Abdirrezzâk el-Bilgrâmî el-Hüseynî. Tâcü'l- 'arûs min cevâhiri'l-kạmûs. Beyrut: y.y., 1994.

Zeydân, Mahmûd. Fî̀ Felsefeti'l-Luga. Beyrut: Dâru'n-Nahdeti'l-'Arabiyye, 1985. 